\title{
Work-related muscoskeletal symptoms and work impairment among workers in Turkish companies
}

\section{Türk şirketlerindeki işçillerde işle illişkili kas- iskelet semptomları ve iş kısıtlılığı}

\author{
Aliye Mandıracıoğlu
}

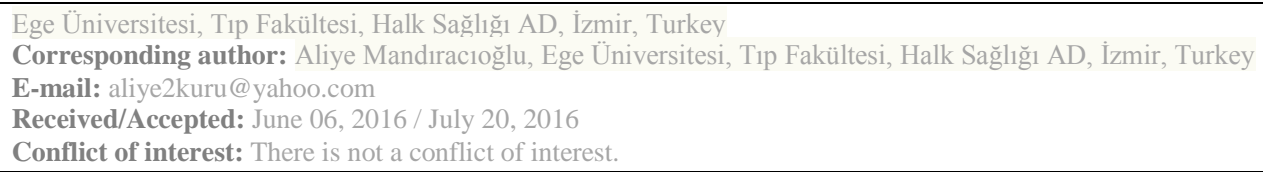

\section{SUMMARY}

Objective: Musculoskeletal disorders are major problems for the working population. The aims of study were to describe musculoskeletal symptoms (MSS) and work impairment among workers and to analyze the relationships between these complaints and work related and individual factors. Method: This was a cross-sectional study. The study population consisted of 498 workers from four different companies in Izmir. A questionnaire including questions relating to sociodemographic characteristics, working conditions, lifestyle factors, body mass index, social relationships and job satisfaction was administered. The General Nordic Questionnaire for MSS was used to examine reported complaints over the past 12 months. Work activity impairment was evaluated by two items in this study. These attempted to determine whether health problems in the last 7 days affected daily life and working life.

Results: Mean age was $35.3 \pm 8.2$ years (range 18-60 years); $79.2 \%$ of participants were male. $67.7 \%$ had experienced MSS in at least one body part during the past 12 months. Lower back pain was the most common MSS. There were no relationships between MSS and the following workrelated factors: type of company, employment status, occupational category, career length, daily working hours, shift work, working overtime, night work, relationships with colleagues. Employees who were satisfied with their jobs and work conditions had a statistically significantly lower rate of complaints. There were significant correlations between poor posture and MSS. There was an association between MSS and work impairment.

Conclusions: Musculoskeletal symptoms were a common problem among workers in the study population. An important risk was work-related poor posture.

Keywords: Workers, Nordic Questionnaire, work-related musculoskeletal disorders, work limitation

\section{ÖZET}

Amaç: Kas iskelet sorunları çalışan toplumun en başta gelen sağlık problemlerinden biridir. Bu çalışmanın amacı çalışanlarda kas iskelet sorunları ve işe bağlı kısıtlılı̆̆ belirlemek, yakınmaları ile bireysel ve işe bağlı faktörler arasındaki ilişkiyi saptamaktır.

Yöntem: Bu kesitsel çalışma, dört farklı işletmede çalışan 498 kişinin katılımı ile gerçekleştirilmiştir. Sosyo-demografik özellikler, iş koşulları, yaşam tarzı özellikleri, vücut-kitle indeksi, sosyal ilişkiler, iş doyumuna ilişkin bilgileri toplamak üzere anket hazırlanmıştır. Son 12 aylık kas iskelet sorunlarını saptamak üzere Genel Nordik anketi kullanılmıştır. Son 7 gün için işe bağlı kısıtlılığın belirlenmesi iki maddelik bir ölçek kullanılmıştır. 
Bulgular: Katılımcıların ortalama yaşı $35.3 \pm 8.2$ yıl (18-60), \%79.2'i erkektir. Son 12 ay içinde vücudun herhangi bir bölümünde en az bir kas iskelet sorunu yaşayan çalışanların sıklığı \%67.7 olarak belirlenmiştir. En sık bel yakınması bildirilmiştir. Kas iskelet sorunları ile iş arkadaşları ile ilişkiler, çalışılan işyeri, yapılan iş, çalışma süresi, günlük çalışma saati, fazla çalışma, vardiyalı çalışma, gece çalışma değişkenleri arasında bir ilişki saptanamamıştır. İşyeri koşulları ve işinden hoşnut olanlarda yakınmalar daha az saptanmıştır. Kötü postür ile çalışması ve yakınmalar arasında ilişkili belirlenmiş̧tir. İ̧e bağlı kısıtlılık ile kas iskelet yakınmaları da ilişkilidir.

Sonuç: Kas iskelet yakınmaları katılımcılar arasında yaygın ve kötü postürün en önemli risk faktörü olduğu belirlenmiş̧tir

Anahtar sözcükler: İş̧̧iler, Nordic anketi, işle ilişkili kas-iskelet bozuklukları, iş kısıtlılığı

\section{INTRODUCTION}

Work-related health problems affect working life negatively. Work-related musculoskeletal disorders (WMSDs) are one of the most common problems. Musculoskeletal disorders (MSDs), which are common in general society, are a lot more common in working life ${ }^{1}$. MSDs are 3-4 times more common in certain industries, including patient care services, transportation, mining and the food processing, textile, leather, clothing, vehicle and furniture sectors ${ }^{2}$.

It is generally difficult to obtain official figures about the prevalence of MSDs. MSDs are one of the leading occupational diseases recorded in the USA, Nordic countries and Japan ${ }^{2}$.They are among the most common diseases $(38 \%)$ in mandatory occupational surveillance in Europe. In the European Union, 35.7-38.8\% of workers have reported that their working life affects their health ${ }^{3}$. The frequency of MSDs varies according to different occupational groups. Handcombe et al. reported that the frequency of MSDs in the last 12 months in a group of workers from different occupationswas $88 \%{ }^{4}$.

Socioeconomic inequalities, low levels of income and education and poor working conditions are the most important factors affecting the frequency of $\mathrm{MSDs}^{5,6}$. Individual characteristics (age, gender, smoking, exercise, anthropometric condition) and biomechanical stress (repetitive motion, extreme joint positions) are also associated with $\mathrm{MSDs}^{7}$. Other factors affecting WMSD are type of work, work environment and psychosocial factors ${ }^{8}$.

Causing symptoms such as pain, WMSDs negatively affect the daily life and activities of individuals in the workplace and cause work impairment and activity impairment ${ }^{9,10}$. Hagberg et al. found a relationship between MSDs and a decrease in self-reported productivity ${ }^{11}$ MSDs have a high economic and social cost for society ${ }^{12}$ and approximately, 7.7 million work days were lost to MSDs ${ }^{3}$.

Determining and eliminating risk factors are prerequisites for the treatment of symptoms and prevention of MSDs. The aim of this study is to determine the prevalence of MSDs and their contributing factors in different sectors.

\section{MATERIALS AND METHODS}

Study population

This descriptive study was carried out in Izmir in 2013, including4 sectors from supermarket, service, food and packaging. A sample selected by a nonrandom method. Study population was readily available to carry out the data collecting and the study sample was convenient. Most of the workers in these workplaces do manual work. A total of 498 white and blue collar workers were participated in the study. The questionnaires distributed to individuals were completed using the self-report method. Workers gave written consent before participating. Approval of the Ege University Ethics Committee was obtained.

\section{Study instruments}

The questionnaire included items about socio-demographic characteristics (age, gender, education, marital status, having children, income), working life (occupation, years worked, daily/weekly working hours, shift/night work/over time), lifestyle factors (smoking, alcohol 
use, physical activity) and health conditions. Physical fitness was assessed by a question on leisure-time exercise (yes/ no). Body mass index was calculated by asking participants their body weight and height. Working conditions at the workplace were investigated. Physical factors (such as postural variation, rate of movement, awkward postures, repetitive movements, prolonged sitting or standing, strenuous arm positions, lifting, repetitive tasks and working at very high speed) and psychosocial factors at the workplace (job satisfaction, social support from colleagues and superiors, satisfaction with working conditions, environmental exposure, vibration, noise, poor indoor climate, heat and cold) were determined.

A questionnaire to determine workrelated MSS was adapted from the modified Nordic questionnaire ${ }^{13}$. The Nordic Questionnaire is an internationally respected instrument designed to evaluation of musculoskeletal complaints in an ergonomic approach. Questions determined the presence of musculoskeletal symptoms in the last year and in the last 7 days. In addition, one item asked "Have you at any time during the last 12 months been prevented from doing your daily work at home, or at work because of the complaint?" Work activity impairment was evaluated by two items in this study. These attempted to determine whether health problems in the last 7 days affected daily life and working life. These Likert-type questions were evaluated on a scale ranging from 0 (no effect) to 10 (health problem prevents working). High scores indicate work impairment ${ }^{14,15}$. The questionnaires were applied through face to face interviews.

\section{Statistical analysis}

Chi-square test or t-test and ANOVA were used to compare the prevalence of MSS according to each variable. Multiple logistic regression was implemented with the variables, including significant risk factors. Statistical significance was set at $\mathrm{p}<$ 0.05.Analyses were conducted using SPSS Version 18.0 (SPSS Inc. Chicago, IL, USA).

\section{RESULTS}

Of participants, $79.2 \%$ were male and $20.8 \%$ female. The majority of participants were married and the largest age group was 30-49. Most participants were high school graduates or had a lower educational level (see Table 1). Smoking was common, but levels of alcohol consumption level were lower. $15 \%$ had at least one chronic health problem and $15 \%$ had a disabled person or a person in need of care in their family. The majority of participants were "workers", who work 8 hours a day, 40 hours a week. The vast majority were found to encounter various physical and environmental risk factors in working life. The proportion of participants who reported that they received support from colleagues and superiors exceeded $80 \%$. Two thirds of participants were satisfied with their jobs and $80 \%$ were satisfied with their working conditions (see Table 2). The frequency of MSS by body region in the last 12 months and in the last 7 days is given in Figure 1. Back and low back complaints were the most commonly reported conditions. The percentages of participants reporting that their activities were affected are shown in Figure 1. 


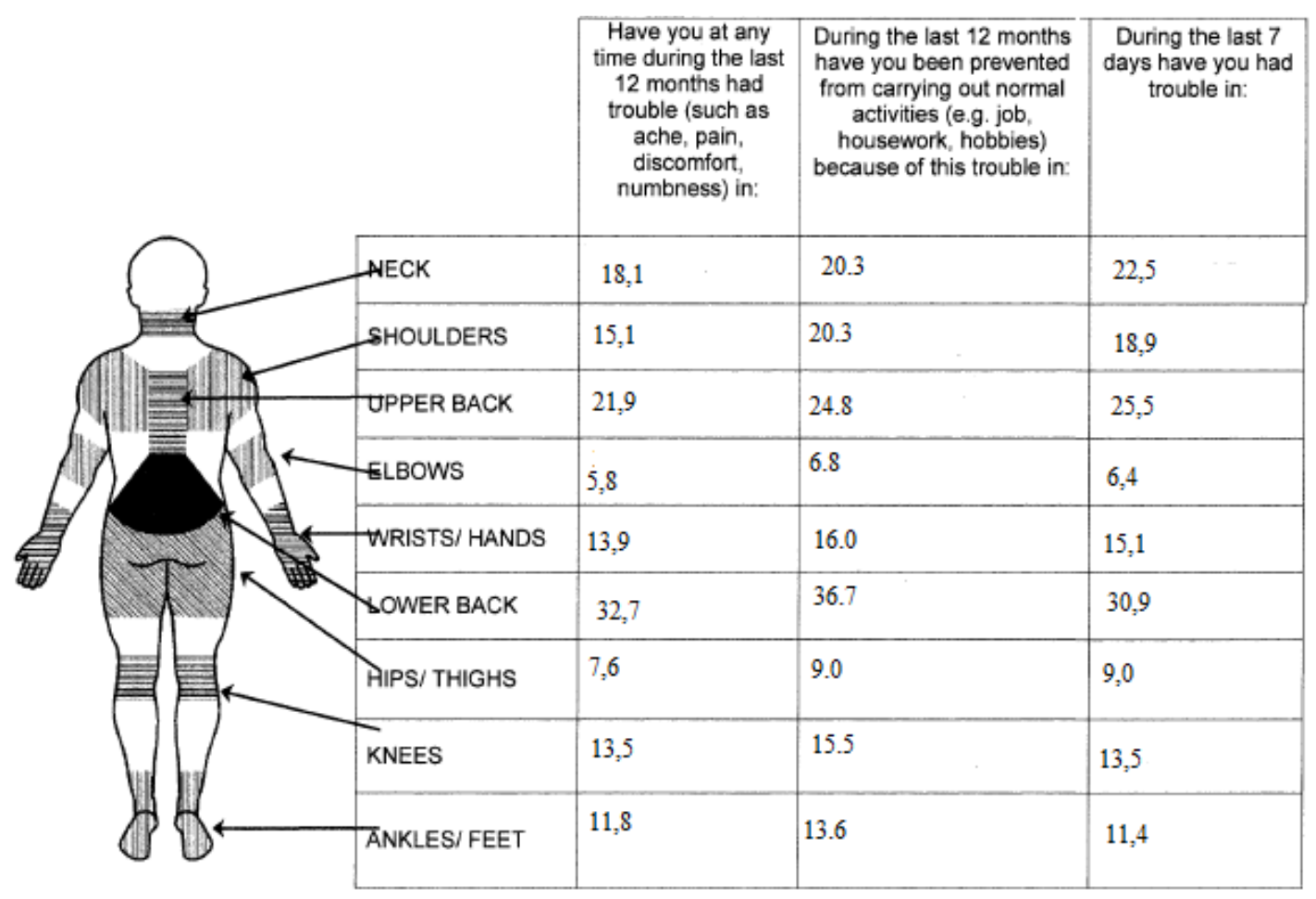

Figure 1.The frequency of MSS among participants

The relationships between musculoskeletal symptoms reported over the last 12 months and sociodemographic and employment variables are shown in Tables 1 and 2. Sociodemographic characteristics, work characteristics and physical, psychological and environmental risks were taken as independent variables and their relationships with MSS frequency were evaluated. In the univariate analysis, some risk factors were associated with MSS. These factors were physical fitness, chronic conditions, family care problems, monotonous work, high speed work, repetitive work, vibration, bad air conditioning, supervisor support, job satisfaction and satisfaction with work conditions. According to the logistic regression analysis, being female (OR:1.76, 95\% CI 1.04-2.95), having problems in the family (OR: 1.97, 95\% CI 1.07-3.63), being dissatisfied with working conditions (OR: 2.35, 95\% CI 1.30-4.23) and doing boring or monotonous work (OR: 2.47, 95\% CI 1.58-3.87) were determined as risk factors for at least one MSS in the last week.

The mean work impairment score of participants was $4.34 \pm 5.01(0-20)$. Work impairment was found to be significantly higher in people who had at least one MSS in the last week $(\mathrm{p}<0.05)$. Work impairment scores according to each body part are shown in Table 3 . 
Table 1. Sociodemographic and life style characteristics and the presence of musculoskeletal symptoms in the last year (Total n: 498)

\begin{tabular}{|c|c|c|c|}
\hline Characteristics & Total $\%$ & $\%$ without MSS & \% with MSS \\
\hline \multicolumn{4}{|l|}{ Gender } \\
\hline Male & 79.2 & 33.6 & 66.4 \\
\hline Female & 20.8 & 27.2 & 72.8 \\
\hline \multicolumn{4}{|l|}{ Age } \\
\hline $18-29$ years & 26.8 & 32.8 & 67.2 \\
\hline 30-39 years & 42.3 & 33.9 & 66.1 \\
\hline 40-49 years & 24.7 & 35.5 & 64.5 \\
\hline 50 years or older & 6.2 & 14.8 & 85.2 \\
\hline \multicolumn{4}{|l|}{ Marital status } \\
\hline Currently married & 73.1 & 29.9 & 70.1 \\
\hline Single & 21.7 & 41.7 & 58.3 \\
\hline Separated/widowed/divorced & 5.2 & 40.0 & 60.0 \\
\hline \multicolumn{4}{|l|}{ Education } \\
\hline Primary School only & 36.5 & 34.4 & 65.6 \\
\hline Middle School & 21.1 & 35.6 & 64.4 \\
\hline High School & 13.4 & 30.3 & 69.7 \\
\hline Vocational School & 14.4 & 35.2 & 64.8 \\
\hline \multicolumn{4}{|l|}{ Having a child } \\
\hline Yes & 32.2 & 37.7 & 62.3 \\
\hline No & 67.8 & 29.9 & 70.1 \\
\hline \multicolumn{4}{|l|}{ Alcohol consumption } \\
\hline Abstainer & 54.9 & 34.0 & 66.0 \\
\hline Former drinkers & 17.2 & 40.0 & 60.0 \\
\hline Currentdrinkers & 27.9 & 25.4 & 74.6 \\
\hline \multicolumn{4}{|l|}{ Smoking } \\
\hline Non-smoker & 38.6 & 34.1 & 65.9 \\
\hline Former smoker & 19.5 & 30.4 & 69.6 \\
\hline Smoker & 41.9 & 31.8 & 68.2 \\
\hline Physically active & 35.7 & 38.8 & $61.2 *$ \\
\hline \multicolumn{4}{|l|}{ Chronic Condition } \\
\hline Present & 15.9 & 15.7 & $84.3 *$ \\
\hline Absent & 84.1 & 36.4 & 63.6 \\
\hline \multicolumn{4}{|l|}{ BMI } \\
\hline$<20$ & 6.6 & 35.5 & 64.5 \\
\hline $20-24.9$ & 35.8 & 37.1 & 62.9 \\
\hline $25-29.9$ & 45.4 & 31.1 & 68.9 \\
\hline $30-39.9$ & 10.5 & 24.5 & 75.5 \\
\hline$>40$ & 1.7 & 25.0 & 75.0 \\
\hline \multicolumn{4}{|l|}{ Family care problems } \\
\hline Yes & 15.1 & 34.3 & $78.7 *$ \\
\hline No & 84.9 & 21.3 & 65.7 \\
\hline
\end{tabular}

*Chi square test, comparison between presence and absence of symptoms $\mathrm{p}<0.05$ 
Table 2. Employment and workplace characteristics and the presence of musculoskeletal symptoms in the last year (Total N: 498)

\begin{tabular}{|c|c|c|c|}
\hline Variables & Total \% & \% without MSS & $\%$ with MSS \\
\hline \multicolumn{4}{|l|}{ Sector } \\
\hline Service Sector & 29.3 & 26.7 & 73.3 \\
\hline Packing Sector & 39.2 & 39.5 & 60.5 \\
\hline SupermarketSector & 10.6 & 28.3 & 71.7 \\
\hline FoodSector & 20.9 & 28.8 & 71.2 \\
\hline \multicolumn{4}{|l|}{ Job } \\
\hline Foreman & 11.6 & 27.8 & 72.2 \\
\hline Technical personnel & 10.1 & 25.5 & 74.5 \\
\hline Manual worker & 56.3 & 34.1 & 65.9 \\
\hline Clerical & 6.5 & 33.3 & 66.7 \\
\hline Other & 15.5 & 34.7 & 65.3 \\
\hline \multicolumn{4}{|l|}{ Years worked } \\
\hline $1-4$ & 16.3 & 33.3 & 66.7 \\
\hline $5-9$ & 25.9 & 32.6 & 67.4 \\
\hline $10-14$ & 19.3 & 31.3 & 68.8 \\
\hline $15-19$ & 13.1 & 24.6 & 75.4 \\
\hline $20+$ & 17.0 & 28.9 & 71.1 \\
\hline \multicolumn{4}{|l|}{ Usual daily working hours } \\
\hline$<8$ hours & 2.2 & 10.0 & 90.0 \\
\hline 8 & 29.9 & 32.3 & 67.7 \\
\hline $8+$ & 67.9 & 33.8 & 66.2 \\
\hline \multicolumn{4}{|c|}{ Usual weekly working hours } \\
\hline $6-40$ & 4.0 & 33.3 & 66.7 \\
\hline $41-47$ & 79.1 & 32.3 & 67.7 \\
\hline $48+$ & 16.8 & 33.3 & 66.7 \\
\hline \multicolumn{4}{|l|}{ Working time schedules } \\
\hline Shifts & 51.2 & 36.1 & 63.9 \\
\hline Nightshift & 46.8 & 39.1 & 60.9 \\
\hline Overtime & 41.0 & 38.7 & 61.3 \\
\hline \multicolumn{4}{|l|}{ Physical factors of work } \\
\hline Tedious and monotonous & 52.8 & 24.3 & $75.7 *$ \\
\hline High speed work & 84.2 & 28.6 & $71.4^{*}$ \\
\hline Repetitous work & 78.1 & 28.1 & $71.9 *$ \\
\hline Working sitting & 46.3 & 34.2 & 65.8 \\
\hline Strenuous for the body & 69.9 & 27.0 & $73.0^{*}$ \\
\hline Bending & 82.1 & 28.6 & $71.4^{*}$ \\
\hline Stretching & 50.7 & 24.5 & $75.5^{*}$ \\
\hline Carrying heavy weight & 68.4 & 27.2 & $72.8^{*}$ \\
\hline \multicolumn{4}{|l|}{ Environmental exposure } \\
\hline Noise & 87.7 & 30.0 & $70.0 *$ \\
\hline Vibration & 36.1 & 31.1 & 68.9 \\
\hline Bad air conditioning & 34.5 & 23.8 & $76.2 *$ \\
\hline Cold /Hot & 81.2 & 30.9 & 69.1 \\
\hline \multicolumn{4}{|l|}{ Social support } \\
\hline \multicolumn{4}{|l|}{ Colleague support } \\
\hline Yes & 83.1 & 33.1 & 66.9 \\
\hline No & 16.9 & 8.0 & 72.0 \\
\hline \multicolumn{4}{|l|}{ Supervisor support } \\
\hline Yes & 82.3 & 35.1 & 64.9 \\
\hline No & 17.7 & 19.7 & $80.3 *$ \\
\hline \multicolumn{4}{|l|}{ Job satisfaction } \\
\hline Not satisfied & 4.2 & 23.8 & 76.2 \\
\hline Neutral & 20.7 & 22.6 & 77.4 \\
\hline Satisfied & 75.0 & 35.8 & $64.2 *$ \\
\hline \multicolumn{4}{|c|}{ Satisfaction with working conditions } \\
\hline Not satisfied & 18.7 & 22.6 & 77.4 \\
\hline Satisfied & 81.3 & 35.5 & $64.5^{*}$ \\
\hline
\end{tabular}

*Chi square test, comparison between presence and absence of symptoms $\mathrm{p}<0.05$ 
Table3. Mean work impairment scores among employees with MSS

\begin{tabular}{|l|c|c|c|}
\hline Body part & Mean \pm SD & T & p \\
\hline Neck & $5.30 \pm 5.06$ & 4.949 & 0.000 \\
\hline Shoulder & $6.31 \pm 5.22$ & 4.581 & 0.000 \\
\hline Elbow & $7.96 \pm 4.77$ & 4.715 & 0.000 \\
\hline Wrist & $6.13 \pm 5.31$ & 3.684 & 0.000 \\
\hline Back & $5.64 \pm 4.78$ & 3.892 & 0.000 \\
\hline Lowback & $5.71 \pm 5.17$ & 4.414 & 0.000 \\
\hline Hip & $6.71 \pm 5.34$ & 3.351 & 0.002 \\
\hline Knee & $6.85 \pm 5.73$ & 4.146 & 0.000 \\
\hline Foot & $7.20 \pm 5.83$ & 4.011 & 0.000 \\
\hline
\end{tabular}

\section{DISCUSSION}

In the work places where the present study was conducted, workers contributed to production at an intensive level physically. The frequency of having at least one musculoskeletal complaint in the last year and in the last week was found to be $67.7 \%$ and $51.5 \%$ respectively. In a study carried out in a sugar factory, MSD symptom frequency in the last year was reported to be $87.1 \%{ }^{16}$. MSS frequency in the last year was reported to be $93 \%$ in an aluminum factory ${ }^{17}$. In another study, the prevalence of musculoskeletal disorders among cashew factory workers was $28.5 \%^{18}$. $39 \%$ of ammunition workers reported at least one musculoskeletal complaint $^{19}$.

The participants in the present study mostly had back and low back complaints. The workers in a sugar factory mostly had knee and low back complaints ${ }^{16}$. The most common problem was found to be low back symptoms among foundry workers 5 . Lower back trouble was reported as a major health problem in forestry workers ${ }^{20}$.

Banibrata noted that most brick field workers suffered from low back pain $^{21}$.The rate of neck, back and low back complaints in office workers in the last 12 months was found to be $42 \%$, $28 \%$ and $34 \%$ respectively ${ }^{22}$. Girish et al found that the largest number of cashew factory workers $(31.4 \%)$ complained of discomfort in the knee ${ }^{18}$.

Working techniques, work organization, psycho-social factors and individual characteristics collectively affect the occurrence of $\mathrm{MSDs}^{20}$. The most common risks encountered in the present study were noise, working at a high speed, working with risk of accident and working in an awkward posture. In a study on the Norwegian oil industry, workers who were exposed to high physical workload and repetitive work were the groups with the most common MSS complaints ${ }^{22}$. Awkward postures and manual handling of materials were the major ergonomic problems in foundry workers 5 . Work posture is directly related to the job and workplace. Especially in industry, the use of many machines is a major risk for the deterioration of work posture ${ }^{24}$. Factors such as poor machine design and location and inadequate lighting are causes of awkward posture ${ }^{25}$.

The frequency of at least one MSS was found to be significantly higher in females. In numerous studies on different professional groups, MSS have been found to be more common in females $^{21,26}$. This is mainly because males have a higher body mass, muscle strength and aerobic capacity ${ }^{26}$.

MSDs in all body regions were found to be more common in people who are not satisfied with their job, not satisfied with 
their working conditions, have a chronic disorder, report problems with caring for family, work in awkward postures (like bending and reaching), or do boring and repetitive jobs. Back, low back, knee and foot complaints in the last year were found to be more common in people who do strenuous movements. On the other hand, back, low back and knee complaints in the last year were found to be more common in people who work at a high speed. Awkward posture, strenuous work and working at a high speed are emphasized as causes of musculoskeletal problems in the literature $^{16,22,27-30}$. In the present study, carrying heavy loads was associated with back and low back MSS. A similar finding has been reported in previous studies ${ }^{16,24,25}$.

In the present study, participants with chronic diseases had significantly higher musculoskeletal symptoms. It has been reported that systemic disorders affect the musculoskeletal system ${ }^{2}$. Previous studies have emphasized that presence of systemic chronic diseases is associated with $\mathrm{MSS}^{19}$.

Negative psychosocial work characteristics are risk factors for MSS ${ }^{29-}$

${ }^{31}$. Ghaffari et al. ${ }^{31}$ found a relationship between being dissatisfied with work and MSS in factory workers. There is some evidence that poor social support, lack of job satisfaction and unsatisfactory relationships at work are associated with MSDs ${ }^{32}$.

Back and low back complaints were found to be the most common complaints in the present study. The relationship between BMI and MSS has also been emphasized in previous studies $^{21,23,30}$. In the present study, the frequency of MSS in all body regions was more common.in people who do not do sport. In the literature, the risk of MSS is reported to decrease in people who do physical activity ${ }^{33,34}$.

The concept of work ability refers to establishing a balance between the resources of the person and the requirements of the job. In the present study, a relationship was found between MSS, work impairment and activity impairment. Neupane et al. found strong relationships between multiplesite pains and poor work ability ${ }^{35}$. Working in poor conditions is a disadvantage in terms of work ability ${ }^{36}$. In a study which assessed MSS using the last two items of the WPAI-GH, MSS were found to cause work impairment in nurses ${ }^{37}$.

The present study has some limitations. Our results are limited in their generalizability because of the sample composition. In addition, musculoskeletal symptoms and work impairment were assessed using the selfreport method.

Work environment has an unquestionable impact on the development of $\mathrm{MSS}^{38}$. Risk factors playa predominant role in $\mathrm{MSS}^{39}$. Ergonomic risk factors and perceived physical demands (postural problems, awkward working postures and static work, repeated action, manual material handling etc.) were found to be the major risk factors in the previous literatures ${ }^{40-43}$.

\section{CONCLUSIONS}

The frequency of MSS in our sample was high. MSS are associated with work limitation. Musculoskeletal disorders are potentially disabling conditions. Therefore, approaches to reduce these disorders in the workplace are important $^{44}$. It is important to examine and discuss personal and workplacerelated factors as MSD is a multifactorial disorder. Measures to be taken in the workplace should not be limited to the workplace. Initiatives in the workplace to reduce personal risk factors will be effective.

\section{REFERENCES}

1. Aptel M, Aublet-Cuvelier A, Cnockaert JC. Work-related musculoskeletal disorders of the upper limb. Joint Bone Spine 2002; 69: 546-55.

2. Punnett L, Wegman DH. Workrelated musculoskeletal disorders: the epidemiologic evidence and the 
debate. J Electromyogr Kinesiol 2004; 14: 13-23.

3. European Agency for Safety and Health at Work, 2010 OSH in figures: Work-related usculoskeletal disorders in the EU-Facts and figures. Available from: https://osha.europa.eu/en/publication s/reports/TERO09009ENC[Lastacce ssed on 2016 June 05]

4. Harcombe H, McBride D, Derrett S, Gray A. Prevalence and impact of musculoskeletal disorders in New Zealand nurses, postal workers and office workers. Aust N Z J Public Health 2009; 33: 437-41.

5. Lei L, Dempsey PG, Xu J, Ge L, Liang Y. Risk factors for the prevalence of musculoskeletal disorders among Chinese foundry workers. Int J Ind Ergon 2005; 35: 197-204.

6. Bergman S. Public health perspective how to improve the musculoskeletal health of the population. Best Pract Res Clin Rheumatol 2007; 21: 191-204.

7. Monteiro MS, Alexandre NM, Ilmarinen J, Rodrigues CM.Work ability and musculoskeletal disorders among workers from a Public Health Institution. Int J Occup Saf Ergon 2009; 15: 319-24.

8. Raanaas RK, Anderson D. A questionnaire survey of Norwegian taxi drivers' musculoskeletal health, and work-related risk factors. Int $\mathbf{J}$ Ind Ergon 2008; 38: 280-90.

9. Escorpizo R. Understanding work productivity and its application to work-related musculoskeletal disorders. Int J Ind Ergon 2008; 38: 291-7.

10. Woolf AD, Vos T, March L. How to measure the impact of musculoskeletal conditions. Best Pract Res Clin Rheumatol 2010; 24 : 723-32.

11. Hagberg M, Tornqvist EW, Toomingas A. Self-reported reduced productivity due to musculoskeletal symptoms: associations with workplace and individual factors among white-collar computer users. J Occup Rehabil 2002; 12: 151-62.

12. Bhattacharya A. Costs of occupational musculoskeletal disorders (MSDs) in the United States. Int J Ind Ergon 2014; 44: 448-54.

13. Kuorinka I, Jonsson B, Kilbom A, Vinterberg H, Biering-Sørensen F, Andersson G. Standardised Nordic questionnaires for the analysis of musculoskeletal symptoms. Appl Ergon 1987; 18: 233-7.

14. Reilly Associates. WPAI: GH V2.0 Turkish. Available from: http://www.reillyassociates.net/.[Las taccessed on 2016June 05]

15. Ciconelli RM, Soárez PC, Kowalski CC, Ferraz MB. The Brazilian Portuguese version of the Work Productivity and Activity Impairment-General Health (WPAIGH) Questionnaire. Sao Paulo Med J 2006; 124: 325-32.

16. Choobineh A, Tabatabaee SH, Behzadi M. Musculoskeletal problems among workers of an Iranian sugar-producing factory. Int J Occup Saf Ergon 2009; 15: 419-24.

17. Aghilinejad M, Javad Mousavi SA, Nouri MK, Ahmadi AB. Workrelated musculoskeletal complaints among workers of Iranian aluminum 1ndustries. Arch Environ Occup Health 2012; 67: 98-102.

18. Girish N, Ramachandra K, Arun GM, Asha K. Prevalence of musculoskeletal disorders among cashew factory workers. Arch Environ Occup Health 2012; 67: 3742.

19. Pinar T, Cakmak ZA, Saygun M, Akdur R, Ulu N, Keles I, et al. Symptoms of musculoskeletal disorders among ammunition factory workers in Turkey. Arch Environ Occup Health 2013; 68: 13-21.

20. Gallis C. Work-related prevalence of musculoskeletal symptoms among Greek forest workers. Int $\mathrm{J}$ Ind Ergon 2006; 36: 731-6. 
21. Das B. Prevalence of work-related musculoskeletal disorders among the brick field workers of west Bengal, India, Arch Environ Occup Health 2014; 69: 231-40.

22. Janwantanakul $P, \quad$ Pensri $P$, Jiamjarasrangsri $\mathrm{W}$, Sinsongsook $\mathrm{T}$. Prevalence of self-reported musculoskeletal symptoms among office workers. Occup Med (Lond) 2008; 58: 436-8.

23. Morken T, Mehlum IS, Moen BE. Work-related musculoskeletal disorders in Norway's offshore petroleum industry. Occup Med (Lond) 2007; 57: 112-7.

24. Xiao G, Dempsey P, Lei L, Ma B, Liang Y. Study on musculo-skeletal disorders in a machinery manufacturing plant. J Occup Environ Med 2004; 46: 241-6.

25. Simoneau S, St-Vincent M, Chicone D. Work-Related Musculoskeletal Disorders: A better understanding for more effective prevention. Institut de Recherche Robert-Sauvé en Santé et en Sécurité du Travail du Québec, 1996. Available from: http://www.irsst.qc.ca/en/-irsstpublication-work-relatedmusculoskeletal-disorders-wmsds-abetter-understanding-for-moreeffective-prevention-rg-126ang.html[Lastaccessed on 2016June05]

26. Kilbom A, Messing K, Thorbjörnsson CB. Women's health at work. National Institute For Working Life. Sweden, 1998. Available from: http://www. forte.se/upload/dokument/ALI\%20p df.../isbn9170454779.pdf [Last accessed on 2016 June 05]

27. Foss L, Gravseth HM, Kristensen P,Claussen B, Mehlum IS, Knardahl $\mathrm{S}$, et al. The impact of workplace risk factors on long-term musculoskeletal sickness absence a registry-based 5-year follow-up from the Oslo health study. JOccup Environ Med 2011; 53: 1478-82.

28. Waters TR, Dick RB, Krieg EF. Trends in work-related musculoskeletal disorders: a comparison of risk factors for symptoms using quality of work life data from the 2002 and 2006 general social survey JOEM 2011; 53: 101324.

29. Nieuwenhuijsen K, Bruinvelsand D, Frings-Dresen M. Psychosocial work environment and stress-related disorders, a systematic review. Occup Med (Lond) 2010; 60: 27786.

30. da Costa BR, Vieira RE. Risk factors for work-related musculoskeletal dis-orders: a systematic review of recent longitudinal studies. Am J Ind Med 2010; 53: 285-323.

31. Ghaffari M, Alipour A, Farshad AA, Jensen I, Josephson M, Vingard E. Effect of psychosocial factors on low back pain in industrial workers. Occup Med (Lond) 2008; 58: 341-7.

32. Eatough EM, Way JD, Chang CH. Understanding the link between psychosocial work stressors and work-related musculoskeletal complaints. Appl Ergon 2012; 43: 554-63.

33. Hildebrandt VH, Bongers PM, Dul J, van Dijk FJ, Kemper HC.The relationship between leisure time, physical activities and musculoskeletal symptoms and disability in worker populations. Int Arch Occup Environ Health 2000; 73: 507-18.

34. Brulin C, Gerdle B, Granlund B, Höög J, Knutson A, Sundelin G. Physical and psychosocial workrelated risk factors associated with musculoskeletal symptoms among home care personnel. Scand $\mathbf{J}$ Caring Sci 1998; 12: 104-10.

35. Neupane S, Miranda H, Virtanen $P$, Siukola A, Nygård CH. Multi-site pain and work ability among an industrial population. Occup Med (Lond) 2011; 61: 563-9. 
36. Pohjonen T. Perceived work ability of home care workers in relation to individual and work-related factors in different age groups. Occup Med (Lond) 2001; 51: 209-17.

37. Letvak SA, Ruhm CJ, Gupta SN. Nurses' presenteism and its effects on self-reported quality of care and costs. Am J Nurs 2012; 112: 30-8.

38. Kaliniene G, Ustinaviciene R, Skemiene L, Januskevicius V. Associations between neck musculoskeletal complaints and work related factors among public service computer workers in Kaunas. Int $\mathrm{J}$ Occup Med Environ Health 2013; 26: 670-81.

39. Descatha A. A conceptual model of musculoskeletal disorders for occupational health practitioners. International Int $\mathbf{J}$ Occup Med Environ Health 2014; 27: 145-8.

40. Choobineh A, Tabatabaei SH, Tozihian M, Ghadami F. Musculo skeletal problems among workers of an Iranian communication company. Indian J Occup Environ Med 2007; 11: 32-6.

41. Inbaraj LR, Haebar OJ, Saj F, Dawson S, Paul P, Prabhakar AP, Mohan VR, Alex RG. Prevalence of musculoskeletaldisordersamongbrick kilnworkers in ruralSouthernIndia. Indian J Occup Environ Med 2013; 17: 71-5.

42. Dabholkar TA, Nakhawa P, Yardi S. Common musculo skeletal problem experienced by fishing industry workers. Indian $\mathrm{J}$ Occup Environ Med 2014; 18: 48-51.

43. Telaprolu N, Anne SD. Physical and psychological work demands as potential risk factors for musculoskeletal disorders among workers in weaving operations. Indian J Occup Environ Med 2014; 18: 129-34.

44. Monteiro MS, Alexandre NM, Ilmarinen J, Rodrigues CM. Work ability and musculoskeletal disorders among workers from a public health institution. Int $\mathbf{J}$ Occup Saf Ergon 2009; 15: 319-24. 